UDK 781.7(540):78.071.2Balaji V.:780.614.33

DOI: 10.4312/mz.54.1.107-122

\title{
Svanibor Pettan
}

Filozofska fakulteta, Univerza v Ljubljani

Faculty of Arts, University of Ljubljana

\section{Lasanthi Manaranjanie Kalinga Dona}

Samostojna raziskovalka

Independent researcher

\section{Ethnomusicology of the Individual: Vishnuchittan Balaji between Tradition and Innovativeness}

\section{Etnomuzikologija posameznika: Vishnuchittan Balaji med tradicijo in inovativnostjo ${ }^{* * *}$}

Prejeto: 4. september 2017

Sprejeto: 11. december 2017

Ključne besede: Etnomuzikologija posameznika, tradicija in inovativnost, Vishnuchittan Balaji, Indija, violina/viola

\section{IZVLEČEK}

Članek se osredotoča na ustvarjalnega glasbenika v kontekstu indijske klasične glasbe, ki spoštuje tradicijo in je hkrati odprt do eksperimentiranja. Temelji na intervjujih in opazovanju z udeležbo ter predstavlja umetnikov miselni svet in njegova štiri inovativna glasbila. Članek sloni na teoretičnem konceptu etnomuzikologije posameznika.
Received: 4th September 2017

Accepted: 11th December 2017

Keywords: Ethnomusicology of the individual, tradition and innovativeness, Vishnuchittan Balaji, India, violin/viola

\section{ABSTRACT}

The article presents the case of a creative Indian classical music artist respectful of tradition and open towards experimentation. Based on the interviews and participant observation, it presents the artist's views and his four innovative musical instruments. The article fits in the theoretical frame of ethnomusicology of the individual.

* This article is a developed continuation of our earlier article in Serbian language titled "Etnomuzikologija pojedinca: Indijski muzičar dr. V. Baladži između teorije i prakse."

** Ta prispevek je nadgradnja znanstvenega prispevka v srbskem jeziku "Etnomuzikologija pojedinca: Indijski muzičar dr. V. Baladži između teorije i prakse.» 


\section{Ethnomusicology of the Individual}

Studies in which scholars discuss broader issues by focusing their attention on worldviews and musicianship of individuals are not very common in the history of ethnomusicology. "Ethnomusicologists nowadays typically understand music individuals as agents who give meaning to - and change - social, cultural, and musical systems in specific instances. This position acts as a corrective to an earlier ethnomusicological theory that music and musicians merely reflect or participate in larger cultural and social processes". ${ }^{1}$ Some ethnomusicologists, such as Mark Slobin, Jonathan Stock and Timothy Rice called for more space for the study of individual agency in the music processes. ${ }^{2}$ Jonathan Stock contributed to a wide recognition of "ethnomusicology of the individual" as one of the prominent directions within the discipline, thanks to a volume of the journal The World of Music with this thematic focus, which he edited in 2001. Stock pointed to three factors that encouraged the rise of ethnomusicological studies of the individual: (a) recognition that certain societies give exceptional attention of exceptional individuals, (b) reappraisal of representational stances in ethnographic writing, and (c) a reconceptualization of "culture" as a mosaic of individual decisions, evaluations, actions, and interactions. ${ }^{3}$ Under the changing overall conditions, musical cultures should not be considered static and unified, but contested, fragmented, deterritorialised, negotiable and increasingly dynamic entities. Jesse D. Ruskin and Timothy Rice conducted an analysis of over a hundred books published in English in the period 1976-2002 and found that about half of them point - at least to some extent - to key figures within the studied musical cultures, one fourth to innovators and another fourth to average musicians. ${ }^{4}$ Ruskin and Rice discuss five selected topics in their coauthored article: (a) the importance of individuals in musical ethnographies, (b) the types of individuals, (c) theoretical purposes of the study of individuals, (d) the nature of ethnomusicologists' encounters with individuals, and (e) narrative strategies, which encompass biography, assisted autobiography, dialogue, polyvocality, and analysis of text and performance (ibid).

Some ethnomusicological studies reveal the focus on an individual by placing his or her name in the title, while the others "hide" such a focus. The representative examples of the former are ,The Voice of Egypt: Umm Kulthum, Arabic song, and Egyptian Society in the Twentieth Century by Virginia Danielson and Fela: The Life and Times of an African Musical Icon by Michael Veal; 5 those of the later include

1 Timothy Rice, Ethnomusicology: A Very Short Introduction (New York: Oxford University Press, 2014), 86.

2 Mark Slobin, Subcultural Sounds: Micromusics of the West (Hanover, NH: University Press of New England, 1993); Jonathan Stock, "Toward an Ethnomusicology of the Individual, or Biographical Writing in Ethnomusicology," The World of Music 43, 1 (2001): 3-34; Timothy Rice, "Time, Place, and Metaphor in Musical Experience and Ethnography," Ethnomusicology 47, 2 (2003): 151-179.

3 Jonathan Stock, "Toward an Ethnomusicology of the Individual, or Biographical Writing in Ethnomusicology," The World of Music 43, 1 (2001): 10.

4 Jesse D. Ruskin and Timothy Rice, "The Individual in Musical Ethnography," Ethnomusicology 56, 2 (2012): 318. The largely obsolete fourth category would be the "nonmusicians", i.e. the audience responsible for the reception of music (ibid, 306).

5 Virginia Danielson, The Voice of Egypt: Umm Kulthum. Arabic Song, and Egyptian Society in the Twentieth Century (Chicago: University of Chicago Press, 1997); Michael Veal, Fela: The Life and Times of an African Musical Icon (Philadelphia: Temple University Press, 2000). 
May It Feel Your Soul: Experiencing Bulgarian Music, in which Timothy Rice features prominent Bulgarian musicians Kostadin Varimezov and his wife Todora, and Michael Bakan's Music of Death and New Creation: Experiences in the World of Balinese Gamelan Beleganjur, featuring in mutually different manners Balinese composers Asnawa and Sukarata. ${ }^{6}$ Other representative ethnographies focus on individual musicians in various parts of the world, such as for instance Taiwan, ${ }^{7}$ Indonesia, ${ }^{8}$ India, ${ }^{9}$ China, ${ }^{10}$ and Greece and USA. ${ }^{11}$

Some ethnomusicological studies, published in the territories of what was Yugoslavia, preceded the just mentioned research outcomes, widely known in the international arena. For example, Cvjetko Rihtman's article on the extraordinary singer from Bosnia and Herzegovina Janja Čičak appeared in $1951 .^{12}$ From the early 1980 s on, Serbian ethnomusicologist Dimitrije Golemović closely collaborated with traditional musician Krstivoje Subotić and consequently wrote about him. ${ }^{13}$ Zmaga Kumer published an article with focus on Slovenian folk singer Katarina Župančič, better known as Živčkova Katra, ${ }^{14}$ while Mira Omerzel and later also Drago Kunej wrote about the instrumentalist and instrument maker Franc Laporšek. ${ }^{15}$ In his book Jest sem Vodovnik Juri: o slovenskem ljudskem pevcu, Slovenian ethnomusicologist Igor Cvetko focused on the late Jurij Vodovnik Tomažič (1791-1858), important author of songs and folk singer; much later, Rajko Muršič wrote about Vodovnik, too. ${ }^{16}$ Since the interest in the individual musicians among Slovenian musicologists continues to reflect the trends in musicology elsewhere and has no impact on ethnomusicology, there is no need for listing the musicological studies dedicated to Western art music individuals here, except for the unusual situation in which an ethnomusicologist writes about a Western art music composer (his father) while a systematic musicologist writes about a traditional music performer (his grandmother). ${ }^{17}$ Among the ethnologists, Marija Makarovič popularized life history research at the turn of the

6 Timothy Rice, May It Fill Your Soul: Experiencing Bulgarian Music (Chicago: University of Chicago Press, 1994); Michael Bakan, Music of Death and New Creation: Experiences in the World of Balinese Gamelan Beleganjur (Chicago: University of Chicago Press, 1999).

7 Jonathan Stock, "Musical Narrative, Ideology, and the Life of Abing," Ethnomusicology 40 (1996): 49-74.

8 David Harnish, "A Hermeneutical Arc in the Life of Balinese Musician, I Made Lebah," The World of Music 43, 1 (2001): 21-41.

9 Regula Burkhard Qureshi, "In Search of Begum Akhtar: Patriarchy, Poetry, and Twentieth-Century Indian Music," The World of Music 43, 1 (2001): 97-137.

10 Helen Rees, "He Yi'an's Ninety Musical Years: Biography, History, and Experience in Southwest China," The World of Music 43 , 1 (2001):43-67.

11 Magrini Tullia, "Repertoires and Identities of a Musician from Crete," Ethnomusicology OnLine 3 (1997) (https://www.umbc. edu/eol/3/magrini/index.html).

12 Cvjetko Rihtman, "Čičak Janja, narodni pjevač sa Kupresa," Bilten Instituta za proučavanje folklora u Sarajevu 1 (1951): 33-63.

13 Dimitrije Golemović, Narodni muzičar Krstivoje Subotić (Valjevo: Narodni muzej, 1984).

14 Zmaga Kumer, "Ljudske pesmi Živčkove Katre," Traditiones 15 (1986): 165-179.

15 Mira Omerzel - Terlep, "Trstenke izdelovalca in godca Franka Laproška," in Zbornik radova 29. kongresa Saveza udruženja folklorista Jugoslavije, edited by Tomislav Đurić (Zagreb: Hrvatsko društvo folklorista, 1991), 459-462; Drago Kunej, "Jaz nisem muzikant, jaz sem ljudski godec. Vloga Franca Laporška pri revitalizaciji trstenk," Traditiones 45, 2 (2016): 83-101.

16 Igor Cvetko, Jest sem Vodovnik Juri: o slovenskem ljudskem pevcu 1791-1858 (Slovenske Konjice: Partizanska knjiga, 1988); Rajko Muršič, "Univerzalne vsebine Vodovnikovega pohorskega pesemskega koša na vstopu v 21. Stoletje," Etnolog 63 (2002): $17-27$.

17 Svanibor Pettan, “Čekajući Mendelssohna: Hubert Pettan (1912-1989)," Arti musices 30, 2 (1999): 221-239; Leon Stefanija, Baba Vita (Ohrid: NU Zavod za zaštita na spomenicite na kulturata i naroden muzej and Struga: NU Naroden muzej d-r Nikola Nezlobinski, 2014). 
centuries, ${ }^{18}$ followed by Mojca Ramšak, who focused on an individual musician in her recent article. ${ }^{19}$ Other articles reflect the opening of ethnomusicology towards various musics and feature e.g. folk-pop singer, ${ }^{20}$ gusle bowed lute player ${ }^{21}$ and renowned accordionist. ${ }^{22}$

\section{An Introduction to the Indian Theme}

Indian classical music is marked by a long and dynamic history paved by creative individuals and their negotiations between tradition and innovation, composition and improvisation, theory and practice, and vocal and instrumental domains. Co-authors of this article - Kalinga Dona was raised in South Asia (Sri Lanka) and received her Master's degree in Indian classical music in India; Pettan was raised in Europe and received education in Indian music mainly in the USA - actively share research interest in Indian classical music. Kalinga Dona‘s M.Mus. supervisor was Vishnuchittan Balaji (the central figure of this article), while Pettan's Ph.D. supervisor was Polish-American ethnomusicologist Jozef Pacholcyzk, author of the seminal book Sufyana Musiqi The Classical Music of Kashmir. ${ }^{23}$ Thanks to Pacholczyk, students at the University of Maryland Baltimore County were exposed not only to his classes on Indian music, but also to many concert-demonstrations, guest lectures of prominent Indian music scholars and musicians, and to the Annual Indian Music Competition in the university compound. Co-authors of this article jointly teach a graduate course on South Asian music at the University of Ljubljana's Department of Musicology, while Kalinga Dona also gives Indian classical violin recitals in Slovenia and abroad. This article is based on Kalinga Dona's fieldwork during her Master's study at the Banaras Hindu University (2002-2004), co-authors' joint fieldwork in Varanasi, India, in 2010, their study of written, audio and audiovisual sources, and on several phone interviews with V. Balaji in 2016 and 2017.

This article is not a place for a comprehensive overview on Indian classical music, but at least a brief overview of the essential distinctions between Carnatic or South Indian classical music and Hindustani or North Indian classical music is necessary for the discussion that follows. In short, the present domains of Carnatic and Hindustani music have shared roots that later evolved into distinctive stylistic legacies due to the centuries of Islamic rule in North India. What do the two have in common? For in-

18 Marija Makarovič, ed., Med vrelci, mlini in klopotci: življenjepisi Radenčanov in okoličanov (Radenci: KUD Bubla, 2000); Marija Makarovič, ed., Pod rečiškim zvonom: življenjske zgodbe Rečičanov in okoličanov (Mozirje: Zavod za kulturo, 2000a); Marija Makarovič, ed., Življenjske zgodbe krajanov Mute in okolice (Muta: Občina, 2001).

19 Mojca Ramšak, "Znanost med objektivnostjo in grožnjo subjektivnosti: vloga terenskih dnevnikov in empatije pri zapisovanju Življenjskih zgodb," Traditiones 31, 2 (2002): 93-114; Mojca Ramšak, "Šest desetletij Avsenikovega glasbeno-poslovnega uspeha," Glasnik Slovenskega etnološkega društva 55/1-2 (2015): 74-85.

20 Ana Hofman, "Lepa Brena: Repolitization of Musical Memories on Yugoslavia," Glasnik Etnografskog instituta 60, 1 (2012): 21-32.

21 Svanibor Pettan, "Gusle revisited: Mile Krajina and the gusle bowed lute in Croatia," In Dara žol: materialy meždunarodnoj naučno-praktičeskoj konferencii posvjaščennoj 90-letiju F. Ž. Balgaevoj, edited by R. K. Musahodžaeva (Astana: Ministerstvo kul’ tury i sporta Republiki Kazahstan; Kazahstanskij nacional’ nyj universitet iskusstv, 2016), 127-133.

22 Vesna Ivkov, Harmonika-život moj: 45 godina umetničkog rada Srboslava - Srbe Ivkova (Beograd: Beogradska knjiga, 2008).

23 Josef Pacholcyzk, Sufyana Musiqi - The Classical Music of Kashmir (Berlin: Verlag für Wissenschaft und Bildung, 1996). 
stance, melodic modality of the $\operatorname{rag}(a)$ system and rhythmic modality of the tal(a) system, affinity for drone as a continuous reference point, small groups of performers sitting on the floor, the guru - shishya parampara traditional way of teaching, sargam (Indian solfege system, including the names of the seven swara pitches within an octave), and consideration of voice as the most perfect musical instrument. Some of the instruments most often associated with India belong either to the Carnatic domain (e.g. veena and mridangam) or to the Hindustani domain (e.g. sitar, sarod, and tabla), while some are regularly used in both domains (e.g. tanpura and violin, which is featured in this article). Carnatic performance is rooted in composition and prefers a steady tempo, while Hindustani performance is characterized by more extended improvisation and gradual acceleration of tempo. The 72 mela scale types in the melakarta system of Carnatic music contrast the 10 thät scale types in Hindustani music. Distinctive are also embellishments such as gamaka (grace) and meend (glide), voice production, aesthetics, techniques including fingering and bowing, and more. ${ }^{24}$

\section{Biographical Data}

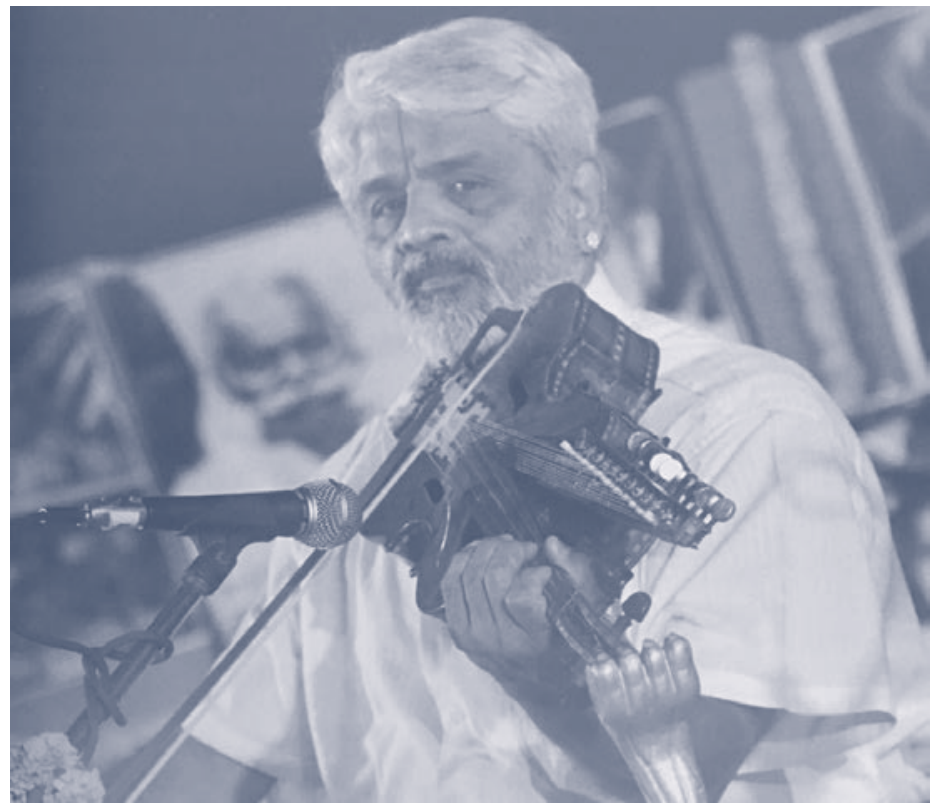

Figure 1: Vishnuchittan Balaji performs at Poorvacharya Smriti Sangit Sammelan, B.H.U. Photo by Neluka Deemantha Liyanage. Varanasi, 2014.

24 For these or other cases see: Gerry Farrell, Indian Music in Education (New York: Cambridge University Press, 1990); Alison Arnold, ed., The Garland Encyclopedia of World Music Vol. 5: South Asia. The Subcontinent (New York: Garland Publishing, 2000); George E. Ruckert, Music in North India (New York: Oxford University Press, 2004); Viswanathan, T. and Matthew Harp Allen, Music in South India (New York: Oxford University Press, 2004). 
Vishnuchittan Balaji was born in 1958 into a family of Carnatic musicians in India's capital city New Delhi, Northern India. His family originates in the village Vadakarai near Chennai ${ }^{25}$ in South India, where his grandfather Shri V. N. Krishna Iyengar established himself as a singer and bansuri (flute) player and his father Shri V. K. Venkata Ramanujam became recognized as a talented violinist. In 1950, at the age of 17, Balaji's father came to New Delhi as accompanist of famous Carnatic singer Dhanda Pani Desikar. Following a successful performance, he received and accepted the offer to join All India Radio national orchestra in the capital city. It was in Delhi, where he established his family and where his son (Vishnuchittan Balaji) was born. Vishnuchittan lived in Delhi only for the first six years of his life, until 1964, before moving to Varanasi ${ }^{26}$ where his father joined the Faculty of Music and Fine Arts at the prestigious Banaras Hindu University (B.H.U.).

V. Balaji's training in Carnatic music began when he was five under the guidance of both his grandfather and father; his father introduced him also to the basics of Hindustani music. He represents the fifth generation of Carnatic musicians in the V.K.V family lineage parampara (school). ${ }^{27}$ In 1975, at the age of 17, he decided to pursue his formal musical training in the Hindustani (and not Carnatic) music. His professor at the B.H.U.'s Faculty of Performing Arts was the renowned female violinist Dr. N. (Narayana) Rajam, who also started as a Carnatic musician in Chennai and later became known for her musicianship in gayaki style in the Hindustani tradition. ${ }^{28}$ Balaji earned all three academic degrees under her guidance at B.H.U.: B. Mus. in 1980, M. Mus. in 1982, and D. Mus. in 1986. After completing the studies, he became about equally involved in Carnatic and Hindustani violin performance, gradually earning respect in India and abroad. While working on his doctorate, he was earning valuable experience as an All India Radio recording artist in Lucknow (1983-85) and Varanasi (1985-93). A recipient of several prestigious awards from the Indian government, he currently teaches at B.H.U.

One episode, necessary for the later discussion, needs to be addressed here. As a professor of violin at B.H.U., Balaji's father V.K.Venkataramanujam came into contact with the American luthier James Wimmer, who later became a frequent guest in their home in Varanasi, learning to perform Indian music on violin and repairing violins. Wimmer's website specifically points to the interest of young Balaji in his work on building and repairing the instruments, and Balaji himself acknowledges the importance of Wimmer in development of his interests and skills. ${ }^{29}$

\section{Individuality}

Vishnuchittan Balaji deeply respects both Carnatic and Hindustani music legacies and practices both at his home. While at B.H.U. and in public perception he, for the

25 A city often referred to as Madras.

26 Varanasi, also known as Banaras, Benares and Kashi, is a city in Uttar Pradesh, North India.

27 V.K.V. is a short form of the musical lineage Vadakarai Krishnaiyengar Venkataramanujam.

28 Gayaki refers to a style that closely resembles expressiveness of human voice in Hindustani instrumental music (more in Alison Arnold, ed., The Garland Encyclopedia of World Music Vol. 5: South Asia. The Subcontinent (New York: Garland Publishing, 2000), 232.

29 More on this interaction can be found at http://www.jameswimmer.com and https://chennaiviolinproject.wordpress.com. 
most part, figures as a Hindustani violinist. Convinced that Carnatic music background considerably boosted performing capacities of his teacher N. Rajam and his own Hindustani musicianship, he goes on in stating, that "technically speaking, Hindustani musicians with Carnatic music background are the best in India" (personal communication, 2016). He points out to his bowing and fingering techniques as the specific aspects of his playing that he inherited from the Carnatic domain. In addition to bridging Carnatic and Hindustani musicianship, he defines his personal style by adding Western violin-playing features, too.

Balaji's respectful attitude towards tradition is evident in his practicing of the gurushishya parampara teaching model. Namely, in addition to the university classroom education at B.H.U., he regularly invites students to join him in musical activities in his home. In other words, he encourages his students to join him collectively when he is practicing in his own private environment, providing them with the opportunity to play with him and to receive his guidance and corrections without additional payment. His wife Shanti and the others in the household treat the students like extended family members, providing them with food, tea, and care in general. On the one hand, he is serious, sometimes even rough when the students make mistakes or express insufficient determination and concentration in the learning process. On the other hand, he graciously shares his both private and professional experiences with the students, aiming to prepare them for the challenges in all life domains, not only musical ones. What he expects from the students is the full respect of his authority. In his own words: "Don't question me, listen to what I say and follow me. I learned music from my grandfather and father and never took a chance to question them. We have to believe our teachers, our forefathers. If I say this is white, accept it as white without arguing with me". ${ }^{30}$ Such an attitude is rooted in his own respect for the art and for the traditional way of transmission of knowledge, understanding, and skills. The following quote does not contradict the previous one, but takes it further from the theoretical prerequisite to the essence of a living practice: "Absorb as much as you can from me, and make sure to develop your own musical personality rather than becoming a copy of Balaji. There is no use of having two Balajis in this world" ${ }^{31}$ Proud of his artistry, hardworking and determined to retain his high standards, he is sensitive, helpful, hospitable, and protective of his students. One of his advices is: "Once you will be invited to give a concert, ask for a fair payment. Low payment would be a humiliation both for the tradition and for your own art. Either ask for a decent payment or perform for free". ${ }^{32}$

Largely improvisational nature of Hindustani music requires considerable concentration. Mental preparation for a concert strongly affects his life days prior to the event. His family members and the students are expected to provide him with a quite but fully supportive environment. He does not practice on a concert day, but thinks intensely on how to optimally shape his musical ideas for the upcoming event. When the time comes, he goes to the concert venue accompanied by the family and students. Chewing

30 Personal communication, 2003.

31 Ibid.

32 Ibid.. 
betel leaves is a habit that helps him relax even on stage. At one concert, after completing the tuning of his instrument, he noticed in the front row some people from another gharana (school) whom he found disturbing. In order to assure a suitable mindset for his performance, he took his betel leaves and while chewing them started to observe the audience, searching for the familiar and supportive individuals to whom he will be able to look at during the playing. After detecting suitable audience members, he was ready to start playing. This nonverbal communication enhances improvisational quality of the performance and prevents him from making any slightest mistake. Despite competitive attitudes and the potentially harmful extents of envy among various schools and individuals, a recent comparative study places Indian classical music to the world's strongest and fully sustainable music cultures. ${ }^{33}$

The unquestionable respect of tradition in his everyday life and musicianship does not prevent Dr. Balaji from experimenting and testing various improvements of his musical instruments. These include adding melodic and sympathetic strings, fingerboards, ribs, bridges, necks, and other elements. In some instances, additional features better suited a more voluminous body of an instrument, thus besides violin, his experiments start to encompass viola, too. Among his most remarkable inventions are the 11-string violin, 25-string violin, 34-string violin, and 15-string viola. Although his basic training is in violin, he freely and equally skilfully applies the same performing techniques to his playing of either instrument. Specifics of these two instruments, elaborated in another scholarly publication, ${ }^{34}$ do not present a challenge for him. "I started my career and established myself as a violinist, which does not prevent me from playing viola. I enjoy playing both instruments. Why would I need to define myself exclusively as a violinist or violist? I am an experimental artist and represent the violin family". 35

What are his motives for challenging the existing standards? Besides his personality-based inner creative needs, he sometimes solves down-to-earth problems, and sometimes tries to bring his Western-originated instrument closer to the Indian sound ideals. Balaji's violin stand demonstrates his problem-solving attitude. "In India the violin is played sitting cross legged, the instrument pointing to the ground with scroll resting firmly on the ankle of the right foot. This allows the left hand to slide freely up and down the neck, without any need for the instrument to be supported by hand or chin". ${ }^{36}$ From his early age, Balaji felt uneasy about direct contact between the instrument and his foot ${ }^{37}$ and thus started experimenting with the stands as early as 1978. This invention not only enabled him to place the scroll of the instrument on the stand (rather than on a foot ankle); it also increased the possibility of eye contact with the audience, which is important for a performing artist. This already developed attitude was further supported by his accident with a

33 More in: Huib Schippers and Catherine Grant, Sustainable Futures for Music Cultures: An Ecological Perspective (New York: Oxford University Press, 2016).

34 Gisa Jähnichen, Chinthaka P. Meddegoda, and Ruwin R. Dias, "Experiencing the Viola in Hindustani Classical Music," Journal of the American Viola Society 31 (2015): 33.

35 Personal communication, 2016.

36 Quotation taken from http://www.fiddlingaround.co.uk/india/.

37 At several instances he compared violin with god and its scroll with god's head. 
bull in 1996, which led to an operation of his left wrist and its consequent sensitivity to bending. Balaji thinks of the stand as particularly suitable for female players. He recently created an advanced stand for his former teacher N. Rajam, suitable for the support of the instrument in three playing positions: sitting on the floor, sitting on a chair, and standing. As a pedagogue, he encourages his students to use a stand, and co-author of this article Kalinga Dona uses it in her performances, as well. Figure 6 demonstrates the two positions of holding the violin, with the stand (Balaji) and without the stand (his son B. Anantha Raman).

The following quote demonstrates the other motive for Balaji‘s innovative attitude: "In 1985, I accompanied singer Pt. Chittaranjan Jyotishi in an All India Radio concert in Varanasi. After the concert he said to me: ,Your playing is superb, but I miss sympathetic sound resonance, like that of sarangi $i .{ }^{38}$ It hurt my feelings and from that day on I started to experiment. Within the next few months, I was able to make a violin with sympathetic strings. And then I continued experimenting further on" ${ }^{39}$ How Balaji's colleagues comment his innovations? "Colleagues say that the sound of my violin is completely different, livelier, and that sympathetic strings give resonance to my playing". And how does he feel about those colleagues who think of tradition in a less dynamic way? "I am in the music scene for more than fifty years. And I am still a student. I don't have enough knowledge to judge anybody. My techniques, just as my instruments, are my own innovations". 40

\section{Experiments and Innovations}

Improvement of an existing musical instruments is a complex artwork, which requires in-depth understanding of the actual instrument, firm knowledge of the material(s) from which it is made of, and technical skills necessary for carrying on the process. In Kevin Dawe's words, "the making of musical instruments (like the playing of them) requires a range of psychobiological, sociopsychological, and sociocultural skills". ${ }^{41}$ What follows is a presentation of Balaji's four completed innovations, based on his own experiments in the course of the last three decades.

\section{Bala bela ${ }^{42}$}

Bala bela is an 11-string violin (Figure 2). It has 4 main strings, 7 sympathetic strings, and 2 bridges - one for the main strings and the other for the sympathetic strings. The outlook of the scroll of Bala bela is reminiscent of a duck face. This violin was named Bala bela by tabla master Kishan Maharaj in 2000.

\footnotetext{
38 Indian bowed chordophone.

39 Personal communication, 2016.

40 Ibid..

41 Kevin Dawe, "The Cultural Study of Musical Instruments," In The Cultural Study of Music: A Critical Introduction, edited by M. Clayton, T. Herbert, and R. Middleton (New York: Routledge, 2003), 275.

42 Bela is the word for violin in Hindi.
} 


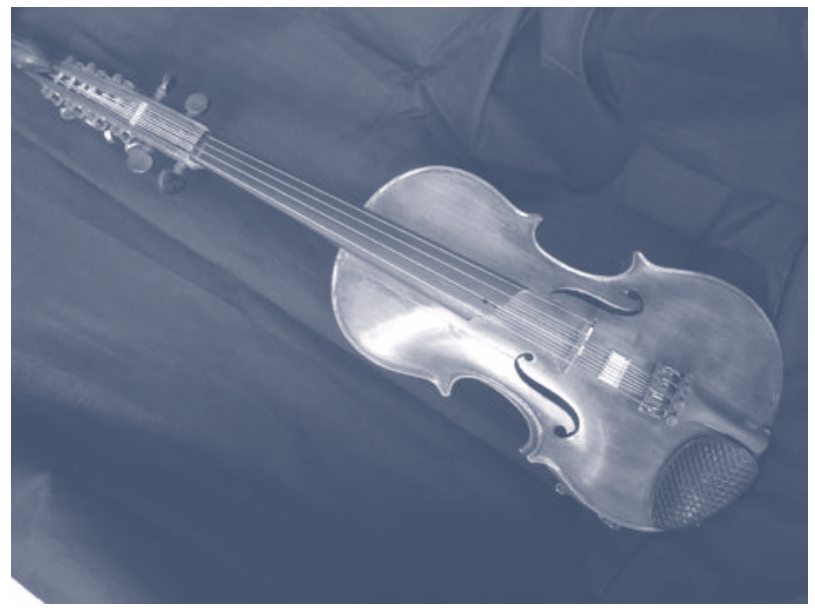

Figure 2: Bala bela. Photo by V. S. Narasimhan. Chennai, 2016.

\section{Triveni bela}

Triveni bela is a 25-string violin (Figure 3). It has 4 main strings representing East, West, South and North, and 3 sets of sympathetic strings. Each set carries 7 sympathetic strings that are divided into 3 rows and point to the three main rivers of India: Ganga, Yamuna and Saraswati. Seven strings in the left (middle octave) resemble Ganga, seven strings in the right (higher octave) resemble Yamuna, and seven strings beneath the fingerboard (lower octave) resemble Saraswati. It has 4 bridges. This violin was dedicated to Banaras Hindu University on the occasion of International Alumni meeting in 2006 at the B.H.U.'s Swantrata Bhavan concert hall.

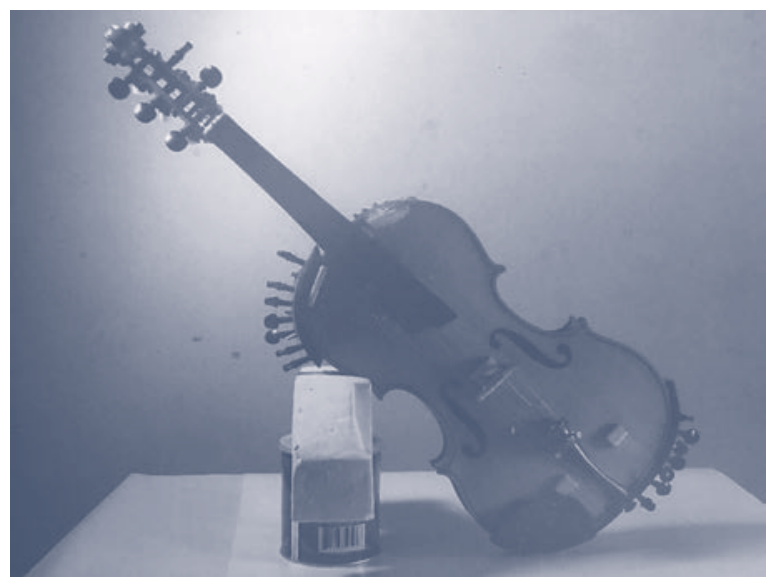

Figure 3: Triveni bela. Photo by Anand Mishra (Graphic Arts, Varanasi). Varanasi, 2006. 


\section{Sringara bela}

Sringara bela is a 34-string violin (Figure 4), dedicated to Balaji‘s mother R. Shringaram. It has double neck, 4 main strings, 5 bridges, 2 sets of 7 sympathetic strings, and 2 sets of 8 sympathetic strings. The left set with 7 sympathetic strings is tuned into a higher octave and the other set, positioned under the fingerboard, is tuned into a lower octave. The right set with 8 sympathetic strings, tuned into a middle octave, is stretched over the second neck, while the other set with 8 sympathetic strings, tuned also into a middle octave, is located on the back side of the violin.

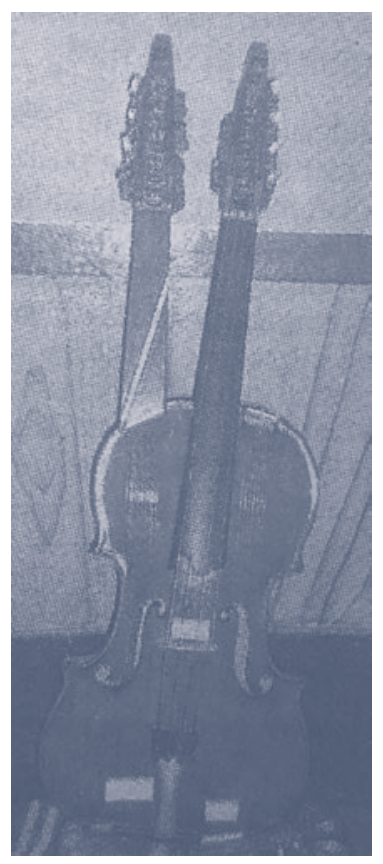

Figure 4: Sringara bela. Photo by Sanjay Gupta (reproduced from local newspaper). Varanasi, 2009.

\section{Rajam bela}

Rajam bela is a 15-string viola (picture 5), dedicated to Balaji's teacher Dr. N. Rajam on the occasion of her 75 th birthday in 2013. It is a combination of violin and viola body, cello back and cello bridge with double rib, double neck - one for sympathetic strings and one for main strings, that produces sounds reminiscent of veena, sarod, rabab, bansuri, sitar, sarangi and violin ${ }^{43}$.

43 Sound of this violin can be experienced at https://www.youtube.com/watch?v=ihJo7oy4__. 


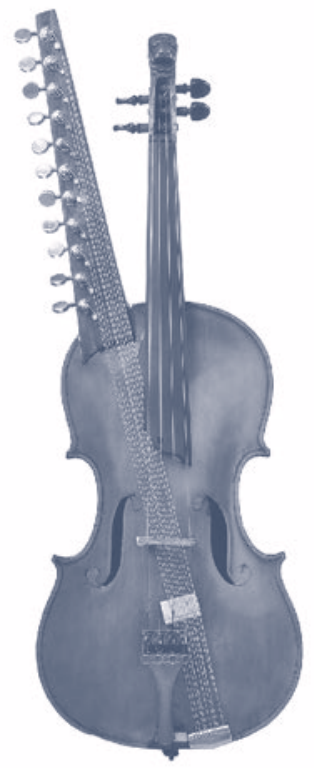

Figure 5: Rajam bela. Photo by Neluka Deemantha Liyanage. Varanasi, 2014.

\section{Conclusions}

"Ethnomusicologists today understand that individuals are agents who enact and challenge social norms, and use music as a resource to do so". ${ }^{44}$ When Baluswamy Dikshitar (1786-1858) introduced Western violin to the Carnatic music in the late $18^{\text {th }}$ century, it was adopted as an instrument to accompany voice..$^{45}$ Due to its resemblance to human voice in timbre and range, it easily earned acceptance all over the Indian Subcontinent. Since then, its function, posture, holding position, tuning, bowing and other playing techniques were subjected to modifications and adjustments. It is too early to speculate whether the innovations of V. Balaji will become widely accepted, but this is not the aim of this article in any way. In words of Roberta Nadeau, "The finished product may at times be a great success or a great failure. It does not matter. What does matter is the continuation of discovery." 46

"Creativity in music needs to be reconceived as a cultural process rather than a heroic act." ${ }^{47}$ Balaji's experimentation is an ongoing process, rooted in the creative personality of an individual musician. Besides music, it is evident in his other artis-

44 Timothy Rice, Ethnomusicology: A Very Short Introduction (New York: Oxford University Press, 2014 ), 50.

45 Ashok Anasuya Kumar and K. S. Venkataraman, Musical Instruments of India (Chennai: Chengacherial Publishers, 2001 ), 23.

46 Roberta Nadeau, "Using the Visual Arts to Expand Personal Creativity," in Using the Creative Arts in Therapy: A Practical Introduction, edited by Bernie Warren (Routledge: London and New York, 1993), 36.

47 Jason Toynbee, "Music, Culture, and Creativity," in The Cultural Study of Music: A Critical Introduction, edited by M. Clayton, T. Herbert and R. Middleton (New York: Routledge, 2003), 110. 
tic activities, including painting and sculpting. Completion of a new artistic product certainly brings satisfaction to him, but he sees it just as a step in a broader creative process rather than as end in itself. Balaji's example clearly supports the notion shared in modern ethnomusicology that "individuals are not simply molded by culture and society but act as agents in the formation of musical cultures." ${ }^{48}$ This case study demonstrates and advocates a dynamic attitude towards the relationship between tradition and innovativeness, pointing out that a good musician needs to internalize knowledge, understanding and skills associated with the tradition and use them as a device for his or her own creative upgrading.

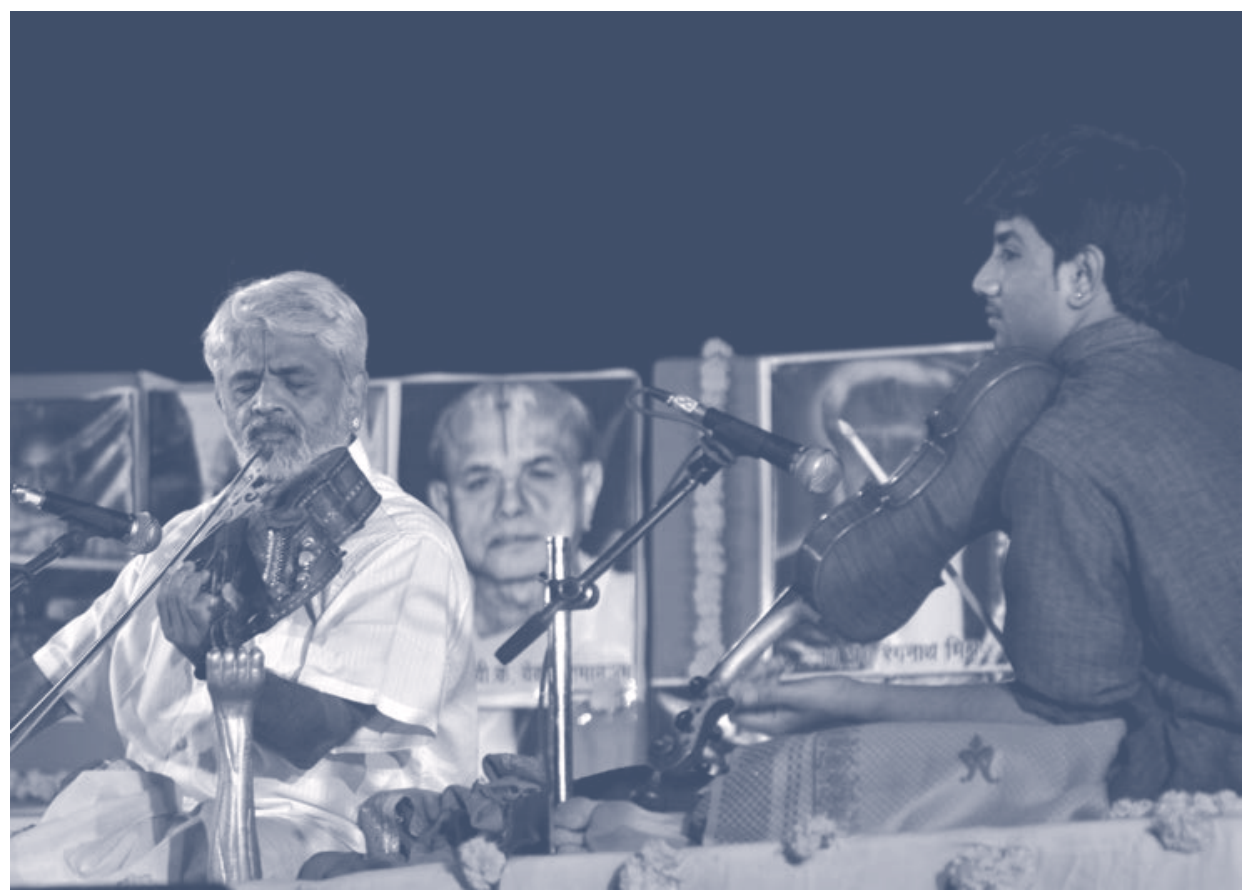

Figure 6: Vishnuchittan Balaji plays Rajam bela using a stand and his son B. Anantha Raman plays by holding his violin in a traditional Indian way. Performance at the Poorvacharya Smriti Sangit Sammelan, B.H.U. Photo by Neluka Deemantha Liyanage. Varanasi, 2014.

The co-authors wish to express gratitude to Dr. V. Balaji for his hospitality at the Banaras Hindu University and in his home, and for his patience at the later phone interviews, as well as to his daughter Bhairavi Balaji Srinivasan for providing them with the photographs and other requested data. Since the publication of this article matches Dr. Balaji's sixtieth birthday, the co-authors are adding their best wishes on the occasion.

48 Timothy Rice, Ethnomusicology: A Very Short Introduction (New York: Oxford University Press, 2014 ), 80. 


\section{Bibliography}

Arnold, Alison, ed.. The Garland Encyclopedia of World Music Vol. 5: South Asia. The Subcontinent. New York: Garland Publishing, 2000.

Bakan, Michael. Music of Death and New Creation: Experiences in the World of Balinese Gamelan Beleganjur. Chicago: University of Chicago Press, 1999.

Cvetko, Igor. Jest sem Vodovnik Juri: o slovenskem ljudskem pevcu 1791-1858. Slovenske Konjice: Partizanska knjiga, 1988.

Danielson, Virginia. The Voice of Egypt: Umm Kulthum. Arabic Song, and Egyptian Society in the Twentieth Century. Chicago: University of Chicago Press, 1997.

Dawe, Kevin. "The Cultural Study of Musical Instruments." In The Cultural Study of Music: A Critical Introduction, edited by M. Clayton, T. Herbert, and R. Middleton. New York: Routledge, 2003, 274-283.

Farrell, Gerry. Indian Music in Education. New York: Cambridge University Press, 1990. Golemović, Dimitrije. Narodni muzičar Krstivoje Subotić. Valjevo: Narodni muzej, 1984.

Harnish, David. "A Hermeneutical Arc in the Life of Balinese Musician, I Made Lebah." The World of Music 43, 1 (2001): 21-41.

Hofman, Ana. "Lepa Brena: Repolitization of Musical Memories on Yugoslavia." Glasnik Etnografskog instituta 60, 1 (2012): 21-32.

Ivkov, Vesna. Harmonika-život moj: 45 godina umetničkog rada Srboslava - Srbe Ivkova. Beograd: Beogradska knjiga, 2008.

Jähnichen, Gisa, Chinthaka P. Meddegoda, and Ruwin R. Dias. "Experiencing the Viola in Hindustani Classical Music." Journal of the American Viola Society 31 (2015): 29-36.

Kumar, Ashok Anasuya and K. S. Venkataraman. Musical Instruments of India. Chennai: Chengacherial Publishers, 2001.

Kumer, Zmaga. "Ljudske pesmi Živčkove Katre.” Traditiones 15 (1986): 165-179.

Kunej, Drago. "Jaz nisem muzikant, jaz sem ljudski godec. Vloga Franca Laporška pri revitalizaciji trstenk." Traditiones 45, 2 (2016): 83-101.

Magrini, Tullia. "Repertoires and Identities of a Musician from Crete." Ethnomusicology OnLine 3 (1997) (https://www.umbc.edu/eol/3/magrini/index.html).

Makarovič, Marija, ed.. Med vrelci, mlini in klopotci: življenjepisi Radenčanov in okoličanov. Radenci: KUD Bubla, 2000.

Makarovič, Marija, ed.. Pod rečiškim zvonom: življenjske zgodbe Rečičanov in okoličanov. Mozirje: Zavod za kulturo, 2000a.

Makarovič, Marija, ed. Življenjske zgodbe krajanov Mute in okolice. Muta: Občina, 2001.

Muršič, Rajko. "Univerzalne vsebine Vodovnikovega pohorskega pesemskega koša na vstopu v 21. stoletje." Etnolog 63 (2002): 17-27.

Nadeau, Roberta. "Using the Visual Arts to Expand Personal Creativity." In Using the Creative Arts in Therapy: A Practical Introduction, edited by Bernie Warren. Routledge: London and New York, 1993, 35-57.

Omerzel - Terlep, Mira. "Trstenke izdelovalca in godca Franka Laproška." In Zbornik radova 29. kongresa Saveza udruženja folklorista Jugoslavije, edited by Tomislav Đurić. Zagreb: Hrvatsko društvo folklorista, 1991, 459-462. 
Pacholcyzk, Josef. Sufyana Musiqi - The Classical Music of Kashmir. Berlin: Verlag für Wissenschaft und Bildung, 1996.

Pettan, Svanibor. "Čekajući Mendelssohna: Hubert Pettan (1912-1989)." Arti musices 30, 2 (1999): 221-239.

Pettan, Svanibor. "Gusle revisited: Mile Krajina and the gusle bowed lute in Croatia." In Dara žol: materialy meždunarodnoj naučno-praktičeskoj konferencii posvjaščennoj 90-letiju F. Ž. Balgaevoj, edited by R. K. Musahodžaeva. Astana: Ministerstvo kul' tury i sporta Republiki Kazahstan; Kazahstanskij nacional' nyj universitet iskusstv, 2016, 127-133.

Pettan, Svanibor and Lasanthi Manaranjanie Kalinga Dona. "Etnomuzikologija pojedinca: Indijski muzičar dr. V. Baladži između teorije i prakse.” In Muzika između teorije i prakse, edited by Vesna Ivkov. Novi Sad: Akademija umetnosti, 2016, 36-49.

Qureshi, Regula Burkhard. "In Search of Begum Akhtar: Patriarchy, Poetry, and Twentieth-Century Indian Music." The World of Music 43, 1 (2001): 97-137.

Ramšak, Mojca. "Znanost med objektivnostjo in grožnjo subjektivnosti: vloga terenskih dnevnikov in empatije pri zapisovanju življenjskih zgodb.” Traditiones 31, 2 (2002): 93-114.

Ramšak, Mojca. "Šest desetletij Avsenikovega glasbeno-poslovnega uspeha." Glasnik Slovenskega etnološkega društva 55/1-2 (2015): 74-85.

Rees, Helen. "He Yi'an's Ninety Musical Years: Biography, History, and Experience in Southwest China." The World of Music 43, 1 (2001):43-67.

Rice, Timothy. May It Fill Your Soul: Experiencing Bulgarian Music. Chicago: University of Chicago Press, 1994.

Rice, Timothy. Ethnomusicology: A Very Short Introduction. New York: Oxford University Press, 2014.

Rice, Timothy. "Time, Place, and Metaphor in Musical Experience and Ethnography." Ethnomusicology 47, 2 (2003): 151-179.

Rihtman, Cvjetko. "Čičak Janja, narodni pjevač sa Kupresa." Bilten Instituta za proučavanje folklora u Sarajevu 1 (1951): 33-63.

Ruckert, George E.. Music in North India. New York: Oxford University Press, 2004.

Ruskin, Jesse D. and Timothy Rice. "The Individual in Musical Ethnography." Ethnomusicology 56, 2 (2012): 299-327.

Schippers, Huib and Catherine Grant. Sustainable Futures for Music Cultures: An Ecological Perspective. New York: Oxford University Press, 2016.

Stefanija, Leon. Baba Vita. Ohrid: NU Zavod za zaštita na spomenicite na kulturata i naroden muzej and Struga: NU Naroden muzej d-r Nikola Nezlobinski, 2014.

Slobin, Mark. Subcultural Sounds: Micromusics of the West. Hanover, NH: University Press of New England, 1993.

Stock, Jonathan. "Musical Narrative, Ideology, and the Life of Abing." Ethnomusicology 40 (1996): 49-74.

Stock, Jonathan. "Toward an Ethnomusicology of the Individual, or Biographical Writing in Ethnomusicology." The World of Music 43, 1 (2001): 3-34. 
Toynbee, Jason. "Music, Culture, and Creativity." In The Cultural Study of Music: A Critical Introduction, edited by M. Clayton, T. Herbert and R. Middleton. New York: Routledge, 2003, 102-112.

Veal, Michael. Fela: The Life and Times of an African Musical Icon. Philadelphia: Temple University Press, 2000.

Viswanathan, T. and Matthew Harp Allen. Music in South India. New York: Oxford University Press, 2004.

\section{Internet sources}

Vishnuchittan Balaji presents Rajam bela and his son B. Anantha Raman demonstrates the playing. Accessed July 25, 2015. https://www.youtube.com/watch?v=ihJo7oy4__Y.

Article from The Hindu newspaper (April 20, 2013). Accessed May 5, 2015. http://www. thehindu.com/features/friday-review/music/violinist-n-rajam-gifted-with-instrument-named-after-her/article4636730.ece

Vishnuchittan Balaji and his son B. Anantha Raman perform on Rajam belas. Accessed July 28, 2015. https://www.youtube.com/watch?v=pNwmreemfKo

Curriculum vitae of Dr. V. Balaji. Accessed May 10, 2015. http://www.bhu.ac.in/performing_arts/instrumental_music/vvalaji.php

A selection of music videos by the Balaji family. Accessed December 22, 2015. https:// www.youtube.com/user/Sangeetamusical90

Fiddling Around the World website. Accessed April 10, 2016. http://www.fiddlingaround.co.uk/india/

James Wimmer's website. Accessed April 10, 2016. http://www.jameswimmer.com

Chennai Violin Project. Accessed April 10, 2016. https://chennaiviolinproject.wordpress.com

POVZETEK

Priznani umetnik na področju indijske klasične glasbe violinist Vishnuchittan Balaji je v članku umeščen v teoretični kontekst etnomuzikologije posameznika, s primeri tovrstne usmeritve v svetovnem merilu in na ozemljih nekdanje Jugoslavije. Študij s poudarkom na posameznih glasbenih ustvarjalcih omogoča bolj poglobljeno razumevanje raziskovalnih problematik, v etnomuzikologiji pa kljub primarnosti terenskega raziskovanja še zmeraj ne sodi k splošno uveljavljenim in sprejetim standardom. V članku so predstavljeni Balajijevi pogledi na življenje, odnos med karnatsko in hindustansko tradicijo $\mathrm{v}$ njegovem glasbenem svetu, pedagoške posebnosti, ki jih prakticira kot profesor violine $v$ hindustanski tradiciji na univerzi Banaras Hindu ter dinamičen odnos med tradicijo in inovativnostjo. Dr. Balaji odlično pozna tradicijo in se zaveda njenega pomena, hkrati pa se loteva eksperimentiranja z namenom boljšega prilagajanja violine potrebam indijske glasbene prakse. V članku so predstavljene štiri inovativne različice violine oz. viole, rezultati njegovih eksperimentov. Študija sloni na terenskem delu ki je vključevalo opazovanje z udeležbo ter intervjuje. 